\title{
Erosion Controlled Extended Release Dosage Form
}

National Cancer Institute

\section{Source}

National Cancer Institute. Erosion Controlled Extended Release Dosage Form. NCI

Thesaurus. Code C42742.

A solid, semi-solid, solution or suspension in which active and/or inert ing redient(s) release is controlled by the erosion rate of a carrier matrix, which is designed to release ing redients at a controlled, prolonged rate so as to reduce dosing frequency. 